\title{
Sosialisasi dan pelatihan pembuatan e-magazine dalam pembelajaran kimia di SMA Negeri Pintar Provinsi Riau
}

\author{
Tri Padila Rahmasari*, Lani Dwi Kurnia, Gesty Mika Juwani, Adek Diah Murti, Khairu \\ Anugrah Perdana Putra, \& Roza Linda \\ Program Studi Pendidikan Kimia, Fakultas Keguruan dan Ilmu Pendidikan, Universitas Riau \\ * tripadila21@gmail.com
}

\begin{abstract}
Abstrak. Salah satu masalah dalam dunia pendidikan adalah pendidik belum bisa menyiapkan materi ajar yang inovatif dan sesuai dengan perkembangan IPTEK. Seiring dengan tuntutan revolusi industri 4.0 yang mengedepankan IT, pendidik dituntut dapat memberikan inovasi untuk meningkatkan minat belajar siswa. Kegiatan pengabdian ini bertujuan untuk memberikan pemahaman dan keterampilan kepada siswa dan guru dalam menggunakan bahan ajar berbasis elektronik melalui sosialisasi dan pelatihan pembuatan e-magazine dalam pembelajaran kimia. Kegiatan pengabdian dilaksanakan di SMAN Pintar Provinsi Riau yang terletak di Taluk Kuantan. SMAN Pintar Provinsi Riau merupakan sekolah berbentuk boarding school yang memiliki infrastruktur dan sarana yang sudah memadai sehingga diperlukan pengoptimalan IPTEK agar sekolah ini bisa berperan serta dalam revolusi industri 4.0. Metode dalam pelaksanaan pengabdian ini adalah pemberian materi berupa sosialisasi tentang pembelajaran abad 21 dan penggunaan e-magazine sebagai bahan ajar pendamping, dilanjutkan dengan pelatihan guru dalam pembuatan e-magazine menggunakan aplikasi Kvisoft Flipbook Maker. Hasil kegiatan pengabdian ini adalah produk e-magazine pembelajaran kimia, buku panduan penggunaan, dan buku tinjauan program. Evaluasi pelaksanaan program pengabdian berupa follow-up kegiatan dengan pemberian kuesioner post-test dan review akhir buku program. Kegiatan pengabdian ini memperoleh respon positif dari siswa dan guru SMAN Pintar Provinsi Riau.
\end{abstract}

Kata kunci: e-magazine; pelatihan; pembelajaran kimia; sosialisasi

\begin{abstract}
One of the problems in education is educators have not been able to prepare innovative teaching materials in accordance with the progress and development of science and technology. Educators are required to provide innovations to increase students' interest in learning, especially in industrial revolution 4.0. This activity aims to provide understanding and skills to students and teachers in using electronic-based teaching materials and training of emagazine making in chemistry learning. The activity was carried out in SMAN Pintar which is located in Taluk Kuantan. SMAN Pintar is a boarding school that has adequate infrastructure and facilities, it requires optimization of science and technology, because of that this school can participate in the 4.0 industrial revolution. The method of implementing this program is the provision of material in socialization about 21st century learning and the use of emagazine as companion teaching materials, followed by training teachers in making e-magazine using Kvisoft Flipbook Maker application. The results of this program are e-magazine products, usage manuals, and program review books. The evaluation of program is follow-up by giving a post-test questionnaire and final review of the program book. This activity received a positive response from students and teachers of SMAN Pintar, Riau Province.
\end{abstract}

Keywords: chemistry learning; e-magazine; socialization; training

To cite this article: Rahmasari, T. P., L. D. Kurnia, G. M. Juwani, A. D. Murti, K. A. P. Putra, \& R. Linda. 2019. Sosialisasi dan pelatihan pembuatan e-magazine dalam pembelajaran kimia di SMA Negeri Pintar Provinsi Riau. Unri Conference Series: Community Engagement 1: 545-554 https://doi.org/10.31258/unricsce.1.545-554

(C) 2019 Authors

Peer-review under responsibility of the organizing committee of Seminar Nasional Pemberdayaan Masyarakat 2019 


\section{PENDAHULUAN}

Berbagai ilmu dipelajari dalam pembelajaran yang dilakukan di institusi pendidikan Sekolah Menengah Atas (SMA). Salah satu pembelajaran tersebut adalah ilmu pengetahuan alam (IPA). Kimia sebagai bagian dari IPA diperoleh dan dikembangkan berdasarkan percobaan untuk mencari jawaban atas pertanyaan apa, mengapa, dan bagaimana tentang gejala-gejala alam, khususnya yang berkaitan dengan komposisi, struktur, sifat, transformasi, dinamika dan energetika zat (Kementerian Pendidikan dan Kebudayaan, 2016). Kimia merupakan salah satu mata pelajaran di sekolah yang dinilai memiliki tingkat urgensi yang tinggi. Selain sebagai mata pelajaran pilihan dalam Ujian Nasional (UN), kimia juga sebagai salah satu mata pelajaran kelompok peminatan dalam kurikulum 2013 yang wajib diambil dalam jurusan MIPA.

Salah satu tugas pendidik adalah menyediakan suasana belajar yang menarik dan menyenangkan. Pendidik harus mencari cara untuk membuat pembelajaran menjadi menarik dan menyenangkan serta mengesampingkan ancaman selama proses pembelajaran. Oleh karena itu, setiap guru membutuhkan serangkaian alat untuk membantu dan mendukung proses pembelajaran tersebut. Salah satu caranya ialah dengan menggunakan bahan ajar yang menarik serta menyenangkan, yaitu bahan ajar yang dapat membuat peserta didik merasa tertarik dan senang mempelajari bahan ajar tersebut. Tidak lupa pula dibutuhkan bahan ajar yang relevan.

Memiliki bahan ajar yang baik adalah poin penting dalam mempelajari kimia, serta dapat memfasilitasi baik guru ataupun siswa saat dalam proses pembelajaran (Direktorat Pembinaan SMA, 2008). Bahan ajar adalah sumber daya yang digunakan guru untuk menyampaikan materi ajar. Materi-materi ini memainkan peranan penting dalam mengakses ilmu pengetahuan serta dapat mendorong siswa untuk terlibat langsung dengan bahan ajar tersebut dengan cara yang berbeda. Adapun bahan ajar yang umum digunakan dewasa ini adalah bahan ajar cetak yang berupa buku teks, LKPD, fotocopy soal, modul serta bahan ajar digital yang berupa powerpoint texts (PPT).

Namun sejak 2016, Kementerian Pendidikan dan Kebudayaan telah mempromosikan gerakan yang disebut "Satu Guru Satu Buku (SAGUSABU)" untuk meningkatkan kemampuan guru dalam menghasilkan bahan ajar. Salah satu contohnya adalah modul. Andi Zulkarnain, dkk (2015) menyatakan bahwa modul adalah alat pembelajaran yang berisi bahan, metode, batasan, dan langkah-langkah yang digunakan secara sistematis dan menarik untuk mencapai kompetensi yang diharapkan sesuai dengan tingkat kerumitan (Direktorat Pembinaan SMA, 2008). Di era industri 4.0 saat ini, modul tidak hanya berupa modul cetak tetapi sudah dikembangkan sebagai bahan ajar berbasis teknologi atau disebut pula dengan e-module.

Materi pengajaran modul cetak dapat dimodifikasi menjadi bentuk glosarium majalah, seperti yang telah dilakukan oleh Wulandari, Azrita, \& Hendri (2016). Terobosan ini muncul karena peserta didik sudah terbiasa dengan kemajuan teknologi dan dapat diamati bahwa peserta didik memiliki pemahaman yang lebih baik tentang teknologi sistem android daripada guru itu sendiri (Syahrowardi \& Permana, 2016). Hal ini sejalan dengan tujuan pendidikan nasional sehingga dalam pembelajaran kimia diharapkan baik peserta didik ataupun guru khususnya mampu menggunakan Teknologi Informasi dan Komunikasi (TIK).

Majalah Kimia atau e-magazine adalah bahan ajar dalam bentuk e-module interaktif. E-magazine sendiri dikemas dalam bentuk compact disk (CD) dan dapat digandakan dalam bentuk file sehingga dapat diakses dengan mudah oleh siswa menggunakan komputer dan berbagai jenis gadget di mana saja dan kapan saja. Modul ini dapat dibuat menggunakan aplikasi flipbook yaitu Kvisoft Flipbook Maker (Syamsurizal \& Chairani, 2015). Kepraktisan semacam ini dapat memperkaya produk digital seperti teks, gambar, audio, video, animasi, flash, dan tautan sehingga menjadikannya sebagai bahan ajar yang sangat menarik (www.kvisoft.com, 2015). Selain itu, dalam e-magazine ini juga terdapat kuis dan latihan soal yang tentunya dapat memudahkan guru dalam mengevaluasi hasil belajar siswa serta dapat mengukur kemampuan siswa dalam memahami pokok bahasan dalam materi ajar.

Ditilik dari beberapa data dan sumber, peminat Ujian Nasional (UN) pada mata pelajaran kimia satu tahun terakhir lebih sedikit dibanding dengan mata pelajaran lainnya. Sesuai dengan polling siswa yang dilakukan oleh detiknews.com pada tahun 2017 terdapat 58\% siswa yang memilih mata pelajaran biologi, $22 \%$ siswa memilih mata pelajaran fisika dan hanya $20 \%$ siswa yang memilih mata pelajaran kimia. Data tersebut menggambarkan bahwa mata pelajaran kimia masih kurang diminati dengan persentase yang tergolong rendah yaitu sebesar $20 \%$.

Selain kurangnya minat siswa terhadap mata pelajaran kimia, hal lain yang menjadikanya kurang diminati adalah pokok bahasan yang terdapat dalam pembelajaran kimia yang dianggap sulit. Roza Linda, dkk (2018) menyatakan bahwa dua dari diskusi terberat berdasarkan kesulitan siswa pada pembelajaran kimia yaitu 
tentang kesetimbangan ionik dan $\mathrm{pH}$ larutan buffer, serta lainnya adalah kesetimbangan kelarutan. Dengan demikian, pokok bahasan tersebut dianggap sebagai bahan yang tepat untuk konten e-module. Dalam kesetimbangan kelarutan dibutuhkan pemahaman menyeluruh tentang teori dan analisis untuk menyelesaikan masalah, serta mahir dalam perhitungan karena konsep dasar terkait kelarutan dijelaskan dalam persamaan matematika.

Berdasarkan hal di atas, maka dilakukan upaya untuk membuat suatu inovasi bahan ajar yaitu melalui sosialisasi dan pelatihan pembuatan e-magazine dalam pembelajaran kimia. Kegiatan pengabdian ini bertujuan untuk memberi pengenalan, sosialisasi dan pelatihan kepada guru dan peserta didik tentang solusi inovatif membuat bahan ajar elektronik yang memiliki tampilan seperti majalah atau biasa disebut $e$-magazine sebagai bahan ajar yang interaktif, menarik dan menyenangkan sesuai dengan revolusi industri 4.0. E-magazine merupakan modul berbasis teknologi dengan tampilan menarik menggunakan aplikasi Kvisoft Flipbook Maker Pro menghadirkan modul yang dapat dimodifikasi dengan tampilan video terkait materi ajar. Pembelajaran abad 21 yang berkenaan dengan teknologi dapat dimulai dengan menggunakan e-magazine sebagai pendamping pembelajaran kimia khususnya materi kimia larutan. E-magazine yang digunakan dalam proses pembelajaran kimia larutan dinamakan dengan EMBER KLASIK. Hal ini merupakan upaya pengoptimalan teknologi dalam pembelajaran. Selain itu, kegiatan pengabdian ini bertujuan untuk memberikan skill atau keterampilan dalam membuat dan menggunakan bahan ajar berbasis teknologi kepada guru sehingga bisa memiliki bahan ajar elektronik yang interaktif, menarik dan menyenangkan sesuai dengan revolusi industri 4.0 serta menerapkannya dalam metode pembelajaran di SMAN Pintar Provinsi Riau.

\section{MASALAH}

SMA Negeri Pintar Provinsi Riau merupakan sekolah rintisan pemerintah daerah Kuantan Singingi dan menjadi salah satu sekolah favorit yang ada di Provinsi Riau berbentuk boarding school. Kurangnya pengoptimalan IPTEK dikalangan masyarakat di era revolusi industri 4.0 khususnya dalam bidang pendidikan, menyebabkan bahan ajar yang tersedia masih bersifat konvensional. Padahal hampir seluruh siswa di SMA Negeri Pintar Provinsi Riau memiliki notebook yang dapat digunakan sebagai penunjang bahan ajar berbasis teknologi. Namun, di sekolah tersebut penyampaian materi ajar masih menggunakan modul berbentuk textbook. Semestinya dengan infrastruktur yang tersedia, pembelajaran berbasis teknologi sudah dapat diterapkan.

Disamping itu, minat siswa SMA Negeri Pintar Provinsi Riau terhadap mata pelajaran kimia masih rendah. Hal ini dapat dilihat dari sedikitnya siswa yang memilih kimia pada mata pilihan Ujian Nasional. Hal tersebut dibuktikan dengan adanya data dari bagian kurikulum SMA Negeri Pintar Provinsi Riau pada ujian nasional tahun 2017, dari 67 siswa sebanyak 54 memilih mata pelajaran biologi, 16 orang memilih mata pelajaran fisika, dan hanya 7 siswa yang memilih mata pelajaran kimia.

Guru kimia yang terdapat di SMA Negeri Pintar Provinsi Riau sebanyak 3 orang dan siswa-siswi SMA Negeri Pintar Provinsi Riau berjumlah 75 orang. Dengan rasio jumlah guru dan siswa, apabila menggunakan bahan ajar cetak dianggap kurang efektif dan tentunya akan memakan biaya yang tidak sedikit.

Berdasarkan permasalahan di atas, maka diperlukan sebuah solusi yang tepat dalam menangani permasalahan tersebut. Salah satunya ialah dengan memanfaatkan elektronik modul sebagai bahan ajar yang interaktif, menarik dan menyenangkan sesuai dengan revolusi industri 4.0 serta menerapkannya dalam metode pembelajaran di sekolah.

Oleh karena itu, diharapkan Program Kreativitas Mahasiswa (PKM) ini dapat membantu peserta didik dan guru dalam menggunakan bahan ajar berbasis teknologi melalui kegiatan pengenalan, sosialisasi, dan pelatihan, sehingga dapat meningkatkan minat peserta didik terhadap mata pelajaran kimia khususnya serta dapat menerapkannya dalam proses belajar-mengajar.

\section{METODE}

Metode pelaksanaan kegiatan pengabdian yang dilakukan dapat dilihat pada gambar 1. Pada tahap persiapan dilakukan survei dan observasi lapangan ke SMAN Pintar Provinsi Riau, Kota Taluk Kuantan Kabupaten Kuantan Singingi. Setelah itu dilakukan persiapan administrasi pembuatan surat izin. Tahap berikutnya adalah persiapan bahan berupa perancangan buku panduan dan buku tinjauan program yang nantinya akan dibagikan kepada peserta. Materi penyuluhan berupa slide presentasi mengenai penggunaan elektronik modul yaitu $e$ magazine, pembelajaran abad 21, dan langkah-langkah pembuatan e-magazine. 
Tahap berikutnya berdasarkan gambar 1 adalah Tahap pelaksanaan, tahap inti dari program ini, kegiatan diawali dengan perancangan kegiatan sosialisasi berupa diksusi dengan pihak sekolah terkait. Dan pemberian kuesioner terkait dengan pembelajaran kimia sekaligus memberikan gambaran umum tentang elektronik modul. Kegiatan kedua adalah sosialisasi terkait pembelajaran berbasis teknologi. Kegiatan ketiga adalah pengenalan program EMBER KLASIK, dan pemberian buku panduan EMBER KLASIK sebagai pedoman penggunaan $e$-magazine serta pemberian buku tinjauan untuk melihat perkembangan penggunaan e-magazine di sekolah dalam jangka pendek. Kegiatan keempat adalah pelatihan e-magazine kepada guru SMA Negeri Pintar Provinsi Riau.

Tahap selanjutnya berupa evaluasi pelaksanaan program pengabdian pada beberapa minggu setelah kegiatan dilakukan. Evaluasi berupa follow-up kegiatan dengan pemberian kuesioner post-test dan review akhir buku program.

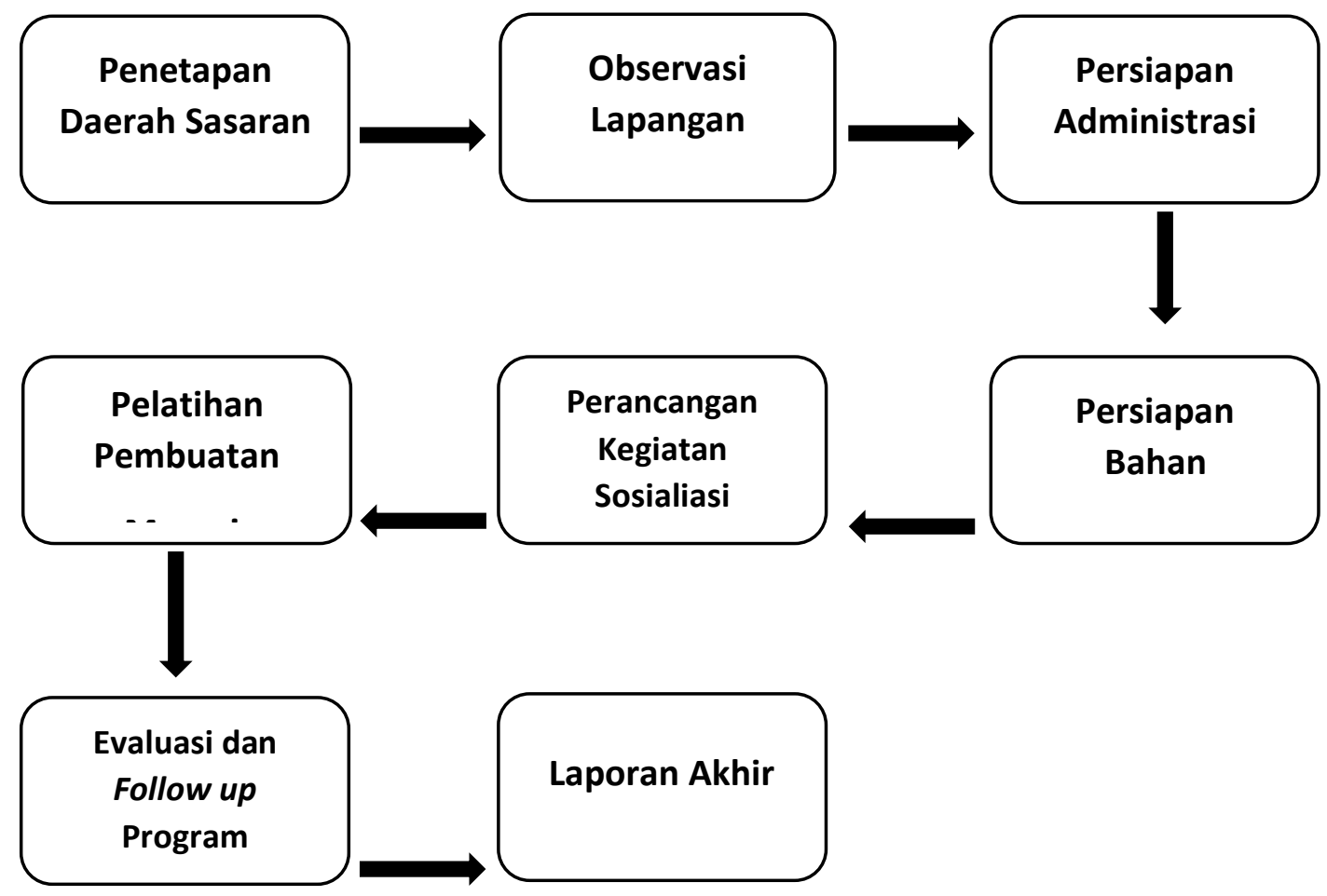

Gambar1. Metode Kegiatan Pengabdian di SMAN Pintar Provinsi Riau

Tahapan dan metode lebih detail dapat dilihat pada tabel 1.

Tabel 1. Tahapan dan metode kegiatan pengabdian masyarakat

\begin{tabular}{|c|c|}
\hline Tahapan & Metode \\
\hline Tahap Awal & $\begin{array}{l}\text { - Melakukan survei lapangan dan mempersiapkan administrasi dan materi } \\
\text { sosialisasi. } \\
\text { - Membuat schedule program yang akan dilaksanakan. }\end{array}$ \\
\hline Tahapan Pelaksanaan & $\begin{array}{l}\text { - Melakukan sosialisasi tentang pembelajaran abad } 21 \text { kepada siswa dan guru } \\
\text { sekaligus memberikan lembar pre-test. } \\
\text { - Melakukan sosialisasi pengenalan e-magazine pembelajaran Kimia kepada } \\
\text { siswa dan guru sekaligus memberikan lembar respon kegiatan. } \\
\text { - Pelatihan pembuatan e-Magazine kepada guru bidang studi Kimia. }\end{array}$ \\
\hline Tahap Akhir & - Melakukan evaluasi dan follow up terhadap masyarakat sasaran. \\
\hline
\end{tabular}


Detail kegiatan adalah sebagai berikut.

1. Penyuluhan.

Penyuluhan bertujuan memberikan definisi, pemahaman dan teori mengenai pembelajaran abad 21. Pada penyuluhan ini juga diberikan pengetahuan mengenai penggunaan e-magazine sebagai bahan ajar pendamping.

2. Pelatihan

Teknik pelatihan sebagai sarana perwujudan upaya pengoptimalan teknologi di SMA Negeri Pintar Provinsi Riau dengan menggunakan e-magazine. Pelatihan dilakukan dengan memberikan praktik langsung kepada tenaga pendidik untuk dapat menciptakan e-magazine secara mandiri.

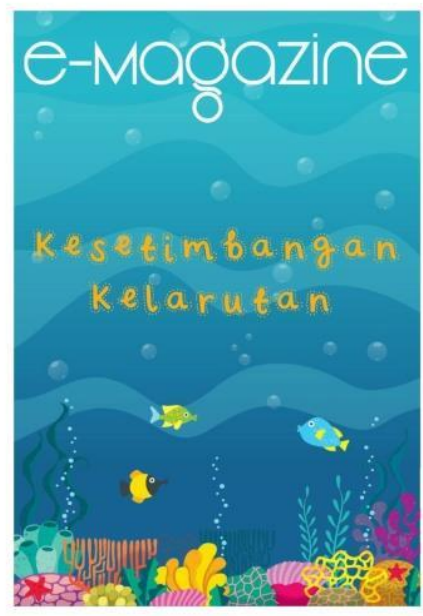

Gambar 2. Desain Salah Satu Bagian dari e-Magazine

Kegiatan ini berlangsung selama 3 bulan meliputi perencanaan, persiapan dan pelaporan. Pokok pokok materi saat sosialisasi adalah:

1. Menampilkan elektronik modul yaitu e-magazine

2. Penjelasan pentingnya pembelajaran berbasis teknologi

3. Menjelaskan cara pembuatan e-magazine

Analisis data yang dilakukan berdasarkan pada kuesioner yang diberikan, kuesioner yang diberikan adalah kuesioner awal sebelum adanya sosialisasi dan kuesioner akhir setelah dilakukan pelaksanaan sosialisasi. Data penunjang lain tentang perkembangan proses belajar mengajar dilihat dari buku tinjauan "EMBER KLASIK" yang diberikan saat sosialisasi di bulan kedua.

\section{PEMBAHASAN}

\section{Luaran kegiatan pengabdian}

1. Memberikan pelatihan terkait E-Magazine kepada siswa dan guru SMA Negeri Pintar Provinsi Riau

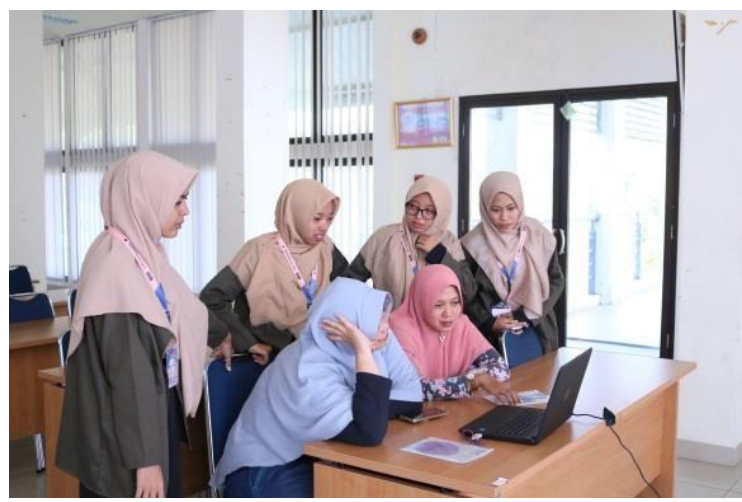

Gambar 3. Pelatihan Pembuatan e-Magazine Ke Guru 


\section{Buku Panduan Program}

Buku panduan program (Gambar 4), digunakan sebagai pedoman penggunaan E-Magazine oleh siswa dan guru yang memuat daftar menu pada e-magazine, fungsi dan cara menggunakannya. Buku ini terdiri atas 29 halaman. Buku panduan mempermudah siswa dan guru untuk mengakses e-magazine menggunakan aplikasi Kvisoft Flipbook Maker Pro.

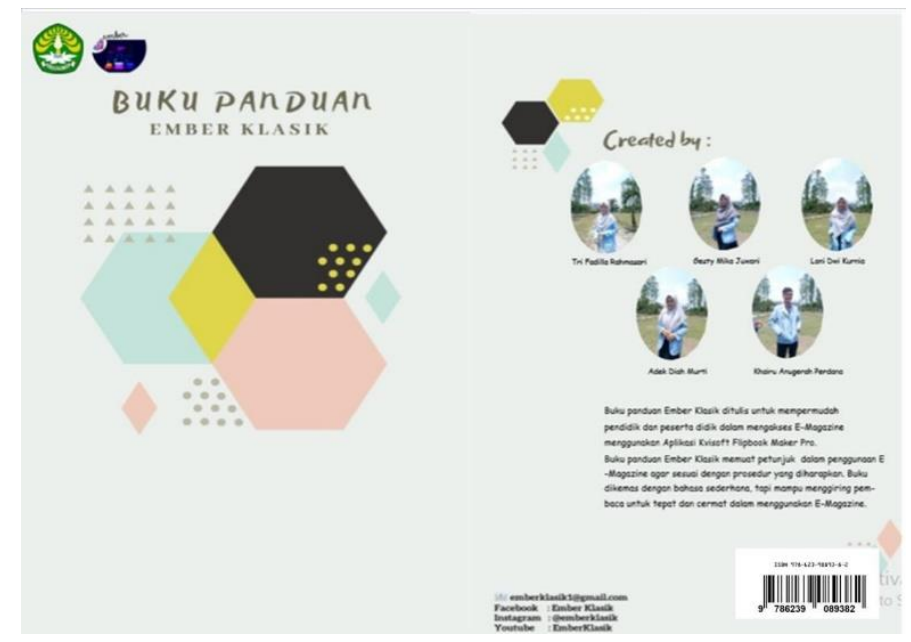

Gambar 4. Buku Panduan Program

\section{Buku Tinjauan Program}

Buku tinjauan program (Gambar 5), berguna untuk memantau sejauh mana penggunaan e-magazine oleh siswa SMA Negeri Pintar Provinsi Riau. Buku tinjauan program terdiri atas 10 halaman. Didalam buku ini terdapat tabel yang memuat hari/tanggal, batas baca/ringkasan dan paraf guru yang menandakan bahwa penggunaan $e$ magazine oleh siswa benar dilakukan. Paraf guru yang terdapat di buku tinjauan merupakan salah satu bentuk pengontrolan oleh guru sejauh mana penggunaan e-magazine oleh siswa.

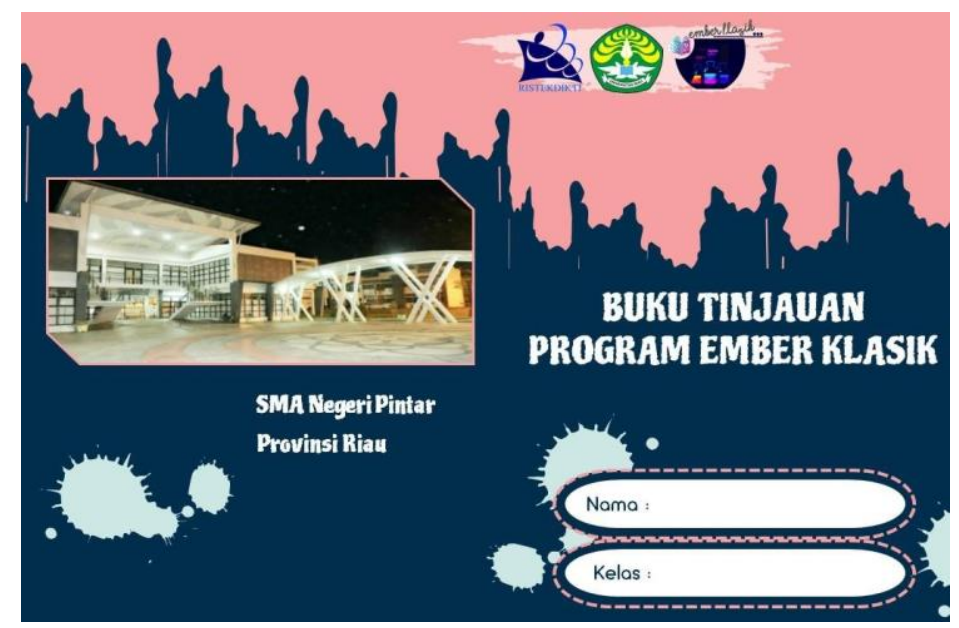

Gambar 5. Buku Tinjauan Program

4. Publikasi media massa melalui koran online maupun cetak, untuk mengenalkan EMBER KLASIK secara menyeluruh 


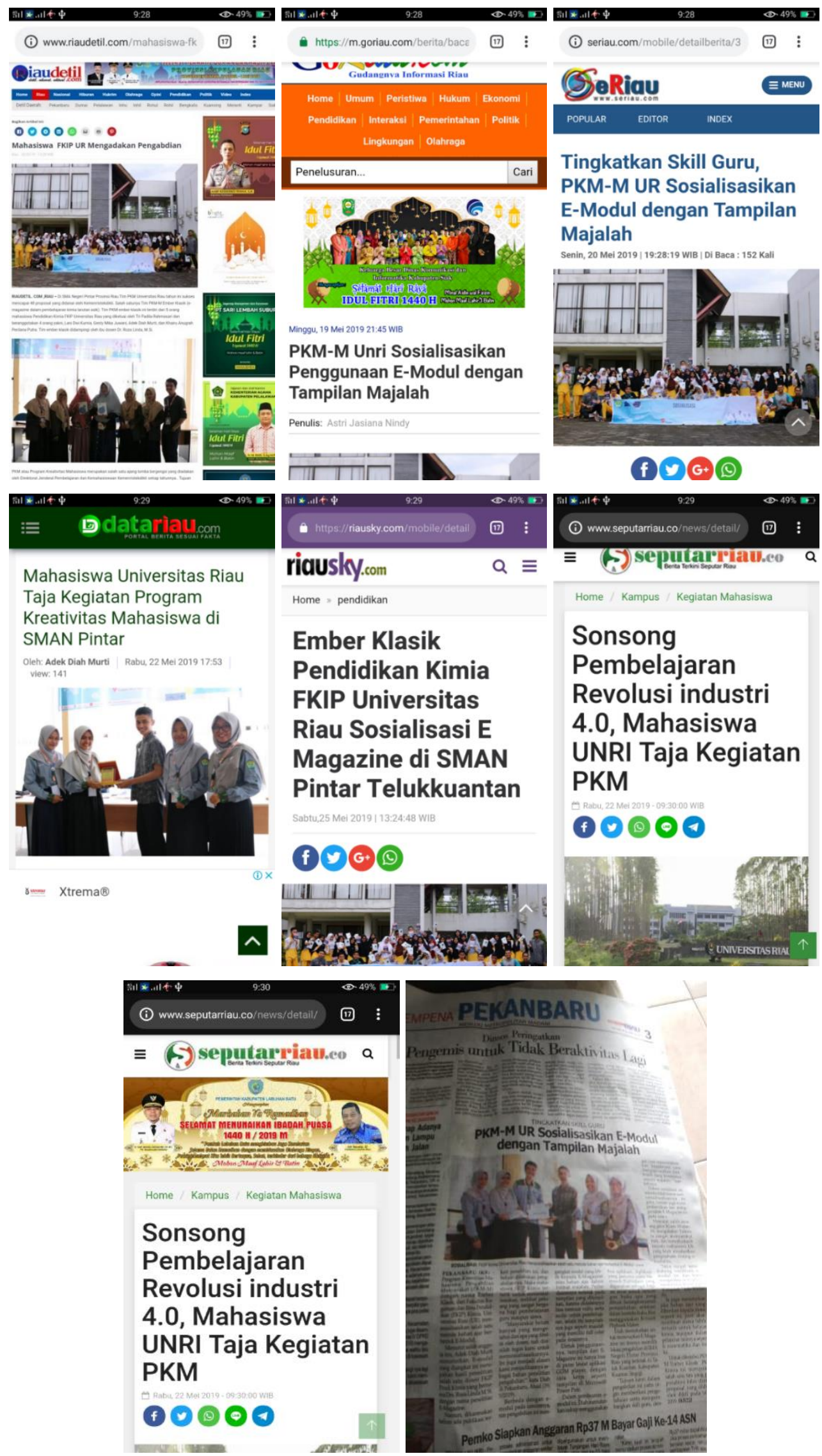

Gambar 6. Publikasi media massa kegiatan pengabdian masyarakat 


\section{Publikasi Artikel Ilmiah}

Artikel ilmiah telah disubmit di Jurnal Sinergitas PKM \& CSR

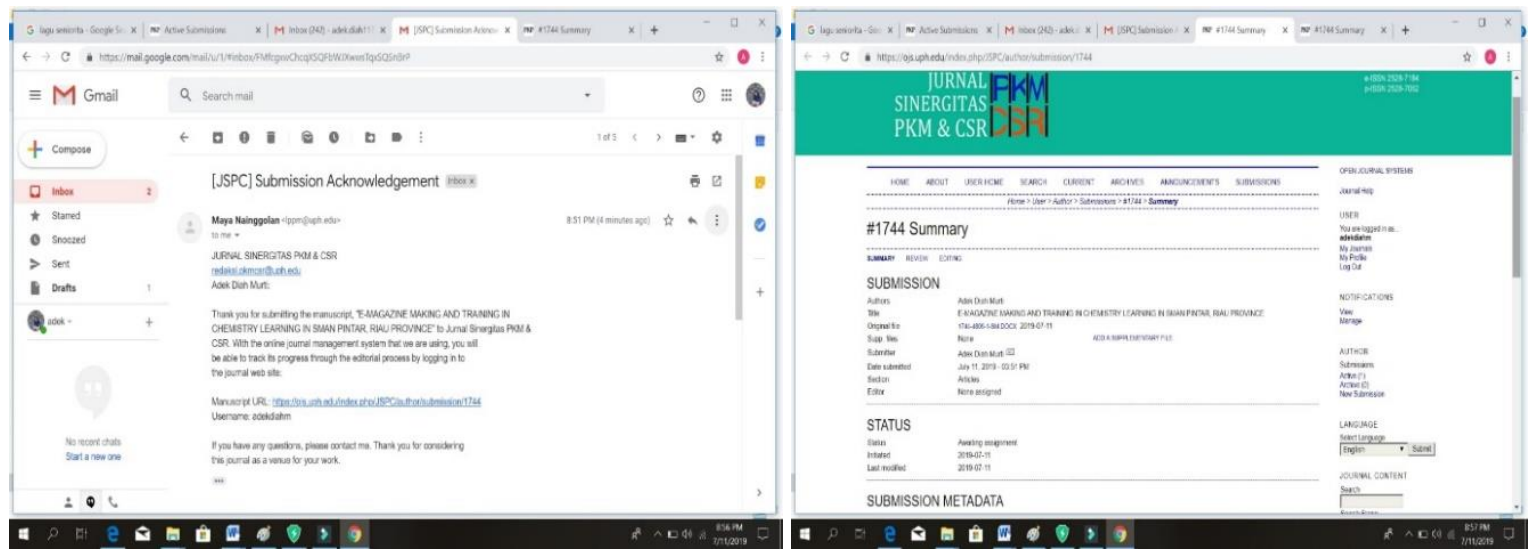

Gambar 7. Artikel Ilmiah

6. Masyarakat mitra dapat melanjutkan penggunaan e-magazine disaat tim PKM tidak menindaklanjuti program, yaitu menciptakan e-magazine dalam subbab pembahasan yang lain.

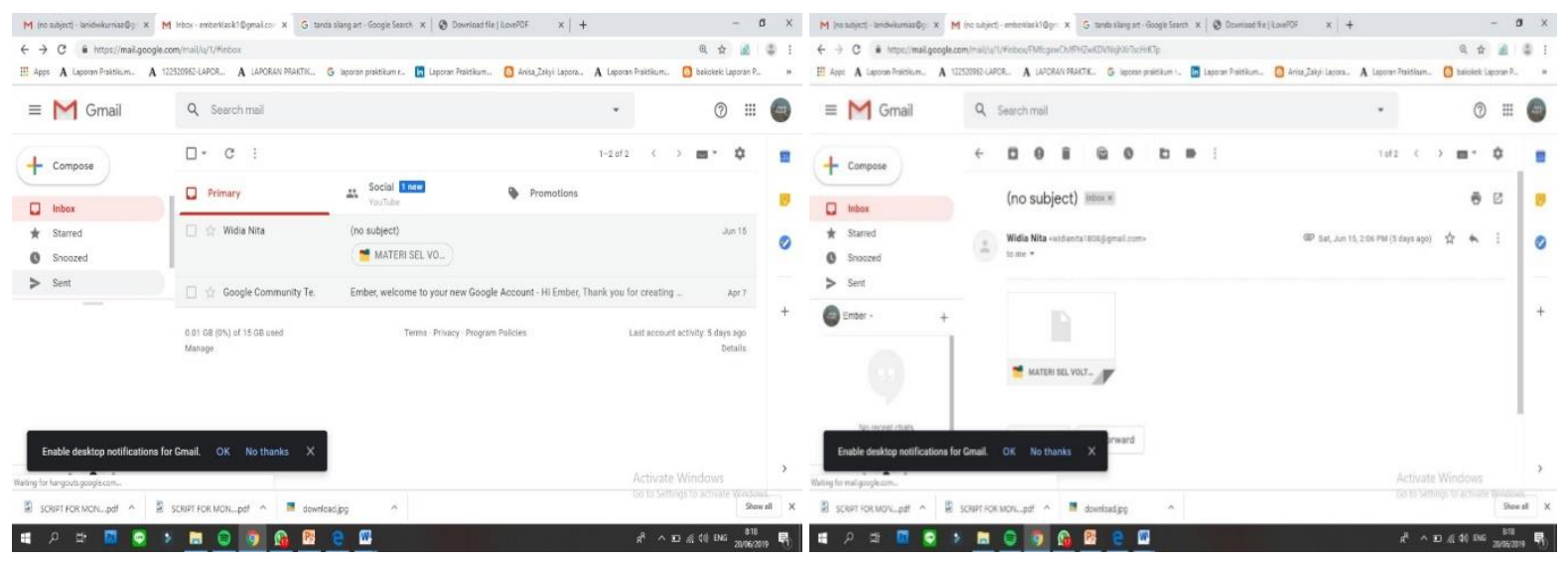

Gambar 8. Bukti e-mail pengiriman E-Magazine baru dari guru sekolah mitra

Beberapa hari setelah penyuluhan dilaksanakan, tim pengabdian masyarakat datang kembali ke lokasi SMAN Pintar Provinsi Riau untuk meninjau kelanjutan kegiatan penggunaan dan pembuatan e-magazine. Guru kimia sebanyak 2 orang telah memberikan hasil dari pembuatan e-magazine. Tim mengambil kembali buku tinjauan yang telah dibagikan kepada siswa sebagai bentuk evaluasi sejauh mana siswa telah membaca e-magazine yang di bagikan. Secara umum, hasil kegiatan menunjukkan bahwa terdapat respon positif dari guru dan siswa SMAN Pintar Provinsi Riau. Survei membuktikan bahwa terdapat kenaikan persentase tes respon yang diberikan kepada siswa dan guru. nilai pre-test guru sebesar 75\% dan post tes sebesar 91,67\% sedangkan pre test peserta didik sebesar $59,26 \%$ sedangkan post tes sebesar $93,08 \%$. Sehingga diperoleh tingkat kenaikannya, untuk guru sebesar $16,67 \%$ dan untuk peserta didik sebesar 33,82\%. Respon guru dan peserta didik terhadap kegiatn pengabdian, yaitu $91,67 \%$ guru setuju dan $93,08 \%$ peserta didik setuju. Merujuk pada kriteria respon guru, nilai tersebut berada pada range persentase $75,00 \%-100 \%$ dengan kriteria setuju, sehingga dapat diperoleh bahwa penggunaan e-magazine dalam pembelajaran kimia kesetimbangan sangat efektif digunakan sebagai bahan ajar pendamping dalam proses pembelajaran. 


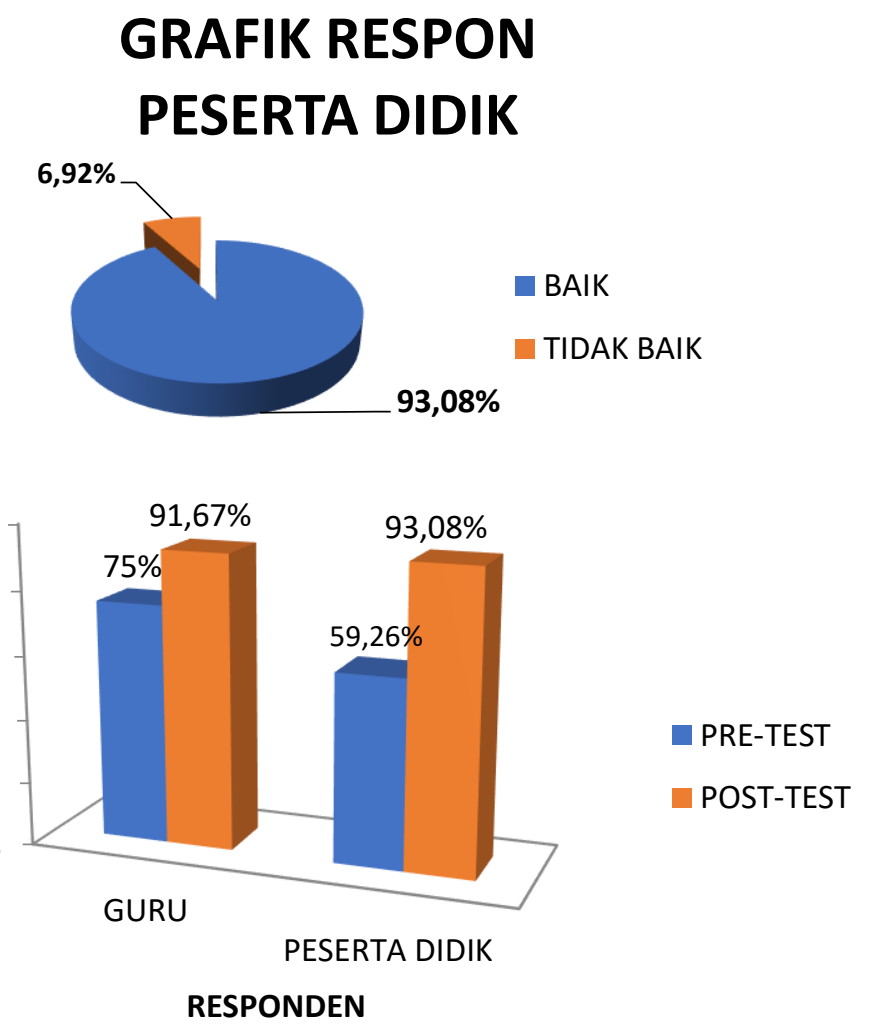

Gambar 9. Grafik respon peserta didik dan guru

\section{Keunggulan dan kelemahan}

Keunggulan dari kegiatan pengabdian masyarakat ini adalah

1. Selain melakukan sosilisasi dan meninjau sejauh mana penggunaan e-magazine selama proses belajar mengajar, kami juga melatih guru dalam pembuatan e-magazine itu sendiri sehingga dapat meningkatkan softskill guru sekaligus menjadikannya sebagai kader dalam sosialisasi e-magazine pada saat MGMP (Musyawarah Guru Mata Pelajaran) di Kabupaten Kuansing agustus yang tentunya program ini akan terus berlanut setelah kegiatan pengabdian ini selesai dilaksanakan.

2. Luaran yang dihasilkan yaitu buku tinjauan sehingga buku ini dapat meninjau sejauh mana peserta didik menggunakan e-magazine. Selain itu, buku panduan program juga merupakan buku yang telah di ISBN kan sehingga buku ini dapat dijadikan panduan dalam menggunakan e-magazine yang tidak hanya bisa digunakan oleh siswa kelas XI saja, namun buku ini juga diberikan kepada pihak sekolah sehingga nantinya diletak di perpustakaan dan digunakan oleh siswa di SMAN PINTAR Provinsi Riau.

Kelemahan dari luaran maupun kegiatan ini adalah

1. Luaran dari kegiatan pengabdian ini yaitu buku panduan program, dimana buku ini masih berbentuk hard file sehingga hanya bisa diakses oleh siswa dan guru di SMAN PINTAR Provinsi Riau. Alangkah baiknya apabila buku panduan ini dalam bentuk soft file yang dionline kan sehingga bisa diakses oleh siapapun.

2. Kegiatan sosialisasi ini hanya dilakukan di SMAN Pintar yang merupakan sekolah boarding school dimana siswanya menggunakan notebook untuk mengakses e-magazine, sehingga e-magazine yang kami gunakan hanya sebatas e-magazine yang diakses di notebook, namun untuk guru bisa diakses di gadget. Alangkah baiknya apabila e-magazine ini bisa diakses di media youtube dan gadget untuk siswa di sekolah lain, sehingga semua orang bisa mengakses e-magazine.

Tingkat kesulitan pelaksanaan kegiatan pengabdian masyarakat yaitu jarak mitra yang jauh dari Pekanbaru. Kendala yang dapat diamati di lapangan adalah penyesuaian waktu kosong yang tepat tim pengabdian bersama dengan pihak sekolah, tetapi guru dan siswa bersedia untuk memakai jadwal liburnya di hari sabtu dan minggu sehingga kegiatan pengabdian bisa dilakukan 


\section{KESIMPULAN}

Berdasarkan hasil kegiatan secara keseluruhan dapat disimpulkan bahwa penyuluhan dan pelatihan pembuatan e-magazine dalam pembelajaran kimia sebagai sarana pengoptimalan teknologi dan meningkatkan kualitas berjalan lancar dan memberikan manfaat besar bagi pihak sekolah dinilai dari respon positif guru dan siswa serta potensi keberlanjutan kegiatan untuk skala luas. Pencapaian target kegiatan telah mencapai 95\% Dari kegiatan ini menjadikan guru kimia SMA Negeri Pintar Provinsi Riau sebagai kader program yang dapat mengajarkan guru lain tentang cara membuat e-magazine sebagai hasil dari pelatihan pembuatan e-magazine. Kegiatan pengabdian ini memberikan dampak positif bagi siswa dan guru yang mengaplikasikan e-magazine sebagai bahan ajar pendamping dalam proses pembelajaran. E-Magazine sebagai solusi efektif untuk pembelajaran berbasis teknologi di era revolusi industri 4.0 yang tidak hanya bisa diterapkan di masyarakat mitra saja, akan tetapi dapat dikembangkan agar bisa digunakan oleh sekolah sederajat se-indonesia dan di Kabupaten Kuantan Singingi pada khususnya. Diharapkan e-magazine menjadi salah satu upaya pengoptimalan teknologi di bidang pendidikan khususnya penggunaan bahan ajar.

\section{UCAPAN TERIMA KASIH}

Penulis mengucapkan terimakasih karena kegiatan ini didanai oleh Direktorat Kemahasiswaan, Kementerian Riset, Teknologi dan Pendidikan Tinggi melalui Program Kreativitas Mahasiswa-Pengabdian Masyarakat (PKMM) tahun 2019.

\section{DAFTAR PUSTAKA}

Andi, Z., N. Kadaritna, \& L. Tania. 2015. Pengembangan E-Modul Teori Atom Mekanika Kuantum Berbasis Web dengan Pendekatan Saintifik. Jurnal Pendidikan dan Pembelajaran Kimia 4(1): 222-235.

Depdiknas. 2006. Kurikulum Tingkat Satuan Pendidikan. Jakarta: Depdiknas.

Direktorat Pembinaan SMA. 2008. Panduan Pengembangan Bahan Ajar. Jakarta: Kementerian Pendidikan Nasional Direktorat Jenderal Manajemen Pendidikan Dasar dan Menengah.

Haryanto, S., \& N. Chairani. Pengembangan e-Modul Berbasis Keterampilan Proses Sains pada Materi Kesetimbangan Kimia untuk Tingkat SMA. Prosiding SEMIRATA 2015 Bidang MIPA BKS-PTN Barat. Pontianak: Universitas Tanjungpura.

Kementerian Pendidikan dan Kebudayaan, 2016, Silabus Mata Pelajaran Kimia Sekolah Menengah Atas/Madrasah Aliyah (SMA/MA). Jakarta: Kementerian Pendidikan dan Kebudayaan.

Kvisoft. 2015. Kvisoft Flipbook Maker. http://www.kvisoft.com/l Diakses pada 15 Desember 2017. 